\title{
The Role of Advertising during Recession
}

\author{
Asst. Prof. Dr. Ayşen Akyüz (Beykent University, Turkey) \\ Asst. Prof. Dr. Mustafa Ercilasun (Beykent University, Turkey)
}

\begin{abstract}
Advertising plays a key role in a dynamic economy. It provides valuable information about products and services in an efficient manner; communicates customer value, builds brand awareness and creates demand. In a recession, the first things that a company usually cuts come from the advertising budget. When companies begin to cut back on advertising during an economic downturn, they become less visible to the public. While it make sense to cut off from communication budget, the evidence shows that the companies which advertise during an economic downturn, have expanded their market share and have maintained their solid image. Therefore according to marketers, neglecting marketing efforts during an economic downturn will result in weakening the brand and making it less profitable in the long run. The present study aims to provide an understanding of the marketing communications' specifically advertising's impact on companies' performance during and after recession. It lays out the theoretical foundations to evaluate the impact of advertising during the recessions and provides some evidence from the world. It is believed to be paramount to examine the existing literature and researches to create awareness in the field, about the importance and impact of advertising during economic downturns.
\end{abstract}

\section{Introduction}

This paper tries to establish a theoretical framework to understand how firms will change their advertising levels and media selections during recession times to optimize their long run profitability. It has been shown that during the economic downturns the level of advertising spending decreases along with declining economic activity (See: Figure 1). Details by world regions for advertising spending and advertising spending growth rates are provided in the appendix. In year 2009, advertising spending growth rates were negative in all world regions except for Latin America though it was the lowest growth rate compared with other years.

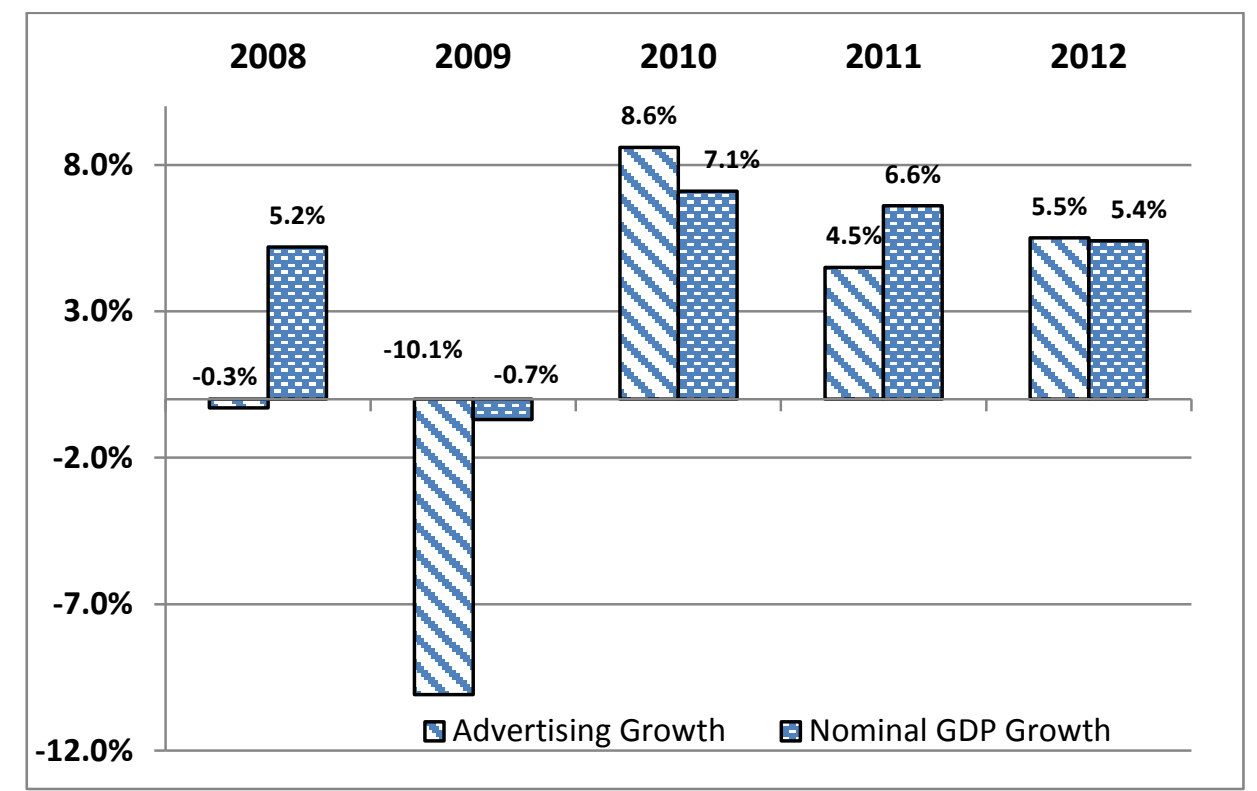

Figure 1: Global Advertising and Nominal GDP Growth Source: Adapted from McKinsey\&Company, Wilkofsky Gruen Associates

Observed positive relationship between economic growth and advertising growth rates is misleading. The truth is, while some firms are cutting their advertising levels, some others are increasing. They are also adjusting media usage and messaging content. Thus it is imperative to, specify conditions under which firms will behave to maximize their long-term profitability carefully. The aim of this paper is to point out the correct way to analyze the behavior of firms during recession times. In doing so, the existing literature will be reviewed and some pitfalls mentioned. Based on this critical review, the proper theoretical approach will be outlined. 


\section{Advertising}

According to marketers, the focal point of the company is the customer. Thus, the primary aim of marketing is to determine the needs and wants of the customer and satisfy them. Acquiring customers, retaining them and catering to demand are paramount for the organizations. In today markets where fierce competition exists, companies have to compete not only against their local competitors, but also against to global competitors. Related to this, the consumer, in alternative evaluation phase of buying decision-making process, is being exposed to and bombarded by several communication messages. In such an environment, the organizations want to be clearly heard by the consumers. No matter how successful and useful the product is, it cannot sell itself. Therefore, the marketing communication efforts become one of the most important instruments in the competition.

The main purpose of marketing communication is to inform the potential consumers about a certain product and service, convey what the product/service promises, present the value proposition and finally send a directive message to the customers, making them perform a specific action such as purchasing. It also plays an important role in connecting with the customer, creating an emotional bond and managing the successful customer relations. As a result, it will not be possible to talk about an effective marketing system without creating effective communication channels.

Being a part of our modern lives, advertising continues its presence to be the companies' most preferred communication medium. It is maybe the one of the most important communication tool in the sense of reaching wide consumer masses, communicating the message effectively, informing the consumer, persuading to try the product, altering the perceptions of the public towards brand, creating brand personality and image. Like the other communication media, advertising influences the mental process of the consumer directly, and is basically related to the individuals' emotions. The advertising can be also thought as a reacting or effecting stimulant. The stimulating effect of the advertising is important for the producer in terms of increasing the demand.

Belch and Belch (2012:698) refers to the economic benefits of the advertising as: The advertising increases the consumption and promotes the economic growth. Advertising, not only informs the consumer about proper products and services; at the same time it facilitates the entrance of a brand/company into new markets.

Economists argue that advertising is used to achieve (1) differentiation, whereby the products or services of large advertisers are perceived as better than competitors' products and services and (2) brand loyalty. The brands that aggressively advertise, dominate the market in certain product categories, such as soft drinks. However, advertising generally doesn't create brand monopolies. In most product categories thousands of new products are introduced to the market every year. The opportunity to advertise gives companies the motive to improve the existing brands and develop new ones. Thus there is no clear evidence that advertising alone reduces competition or creates barriers to entry. Ultimately, the economic benefits of advertising show that a healthy competitive environment between the producers would be developed and the life standards would be improved through the prudent usage of the resources (Belch and Belch, 2012, p.699-701).

As it is stated, large advertisers get benefit of certain competitive advantages including economies of scale in advertising, especially to factors such as media cost. Heavily advertised brands usually sell more, which means they may have lower production costs and can invest more on advertising (Belch and Belch, 2012, p.699-701).

Advertising is very effective, informing about products and services and it plays a favourable role in the progress of the economy. As it is mentioned several times in the literature, advertising creates new demand and stimulates existing demand. It contributes to the improvement of quality and new product development and it shapes the competition and ultimately surge the production and leads to higher sales. As a result, there would be an increase in employment in order to satisfy the demand; sequentially an increase in productivity and ultimately the cycle would be completed with the customers spending more.

\section{Recession}

As discussed above the benefits of advertising to businesses already well established. However, there exist a dispute for advertising around recession times. In economics, the declining portion of a business cycle is called recession. Economists have some disagreements on how to define recession. The standard textbook definition considers two or more consecutive decline in GDP as a recession. This definition of a recession makes it difficult to identify the beginning and ending of a recessionary period. Additionally, it ignores other economic indicators such as unemployment and consumer confidence.

In the United States, the National Bureau of Economic Research (NBER) keeps track of business cycles and declares when the economy goes into a recession. According to Business Cycle Dating Committee of NBER recession is observed by looking at the change in employment, industrial production, real income and sales. They define recession as the time when business activity has reached its peak and starts to fall until the time when business activity bottoms out. The following tables show last four recessions in the United States and Turkey. 


\begin{tabular}{|l|l|c|}
\hline Peak month & Trough month & $\begin{array}{c}\text { Duration (in months) Peak } \\
\text { to Trough }\end{array}$ \\
\hline July 1981 & November 1982 & 16 \\
\hline July 1990 & March 1991 & 8 \\
\hline March 2001 & November 2001 & 8 \\
\hline December 2007 & June 2009 & 18 \\
\hline
\end{tabular}

Table 1: US Business Cycle Contractions Source: http://www.nber.org/cycles/cyclesmain.html

\begin{tabular}{|l|l|c|}
\hline Peak month & Trough month & $\begin{array}{c}\text { Duration (in months) } \\
\text { Peak to Trough }\end{array}$ \\
\hline March 1994 & March 1995 & 12 \\
\hline September 1998 & November 1999 & 14 \\
\hline January 2001 & February 2002 & 13 \\
\hline August 2008 & September 2009 & 14 \\
\hline
\end{tabular}

Table 2: Turkish Business Cycle Contractions Source: http://www.turkstat.gov.tr/,

Many marketers who view recessions just as a decline in economic activity may follow wrong path. It is advisable to consider all aspects of a recession such as decline in income, increased unemployment, and fear to lose potential income and lost jobs etc., for consumers. For businesses it may mean uncertainty for future, less liquidity, increased cost of production. Thus, to understand advertising behavior of firms during recessions it is appropriate to go by broad definition of a recession as it is done by NBER. During recessions some businesses may cut expenditures like research \& development, unnecessary travel and advertising while consumers may cut unnecessary spending; higher ticket items like durables and postpones car \& home buying activity.

\section{Advertising during Recession}

During an economic downturn, it may seem logical for organizations to cut off expenses. In those times saving is much more important than spending. Expenses that a company usually cuts first, come from the advertising budget. However this decision can be argumentative. On one hand, there is a negative economic environment where because of the negative media reporting, there would be a decline in demand for the products and services and eventually companies would want to save more than they spend. But on the other hand when the companies cut back advertising expenditures, they become less visible to public.

Businesses should be aware of the opportunities that a recession can provide. Since the rivals reduce marketing efforts, there may be an opportunity for the businesses to come clear on the eyes of its target market by maintaining a strong advertising campaign during a recession. There may not be a better time to advertise than this, since many others' tendency is to reduce advertising spending. Thus, when advertising aggressively in the economic downturn, an organization might drive and maintain awareness, build a greater market share, with a more solid brand image. Advertising expenditure can be a sign of how marketers believe in their brands and it can give a sense that the advertising brand is strong and reliable than the others that do not advertise. According to the literature, the organizations that invest on advertising during a recession would increase its sales not only during the time of recession but also after the recession. The following paragraphs mentions some references regarding the issue.

Customers, during recession, search for information about a product/service instead of commercial. To gain the trust of the customers, companies should give them the right message with clear information including motives as durability, overall quality and safety (Hruzova, 2009, p: 12; Shrager, 1991).

In economic downturns, marketing can provide important functions with beneficial effects. There is a dynamic environment, constantly changing, therefore it is important for marketers to understand the changes and know how to react to them (Hruzova, 2009, p: 6; Ferrel and Hartline, 2002). Firms may view recession as an opportunity that they have control on the situation and outcome and continue to invest. On the contrary, the firms, which view recession as a threat, end up with conserving their resources (Hruzova, 2009, p: 6; Srinivasan et.al. 2008).

Some important researches were undertaken to explore the relationship between advertising and business cycle. The most important ones are summarized in the following paragraphs.

According to the analysis conducted by the American Business Press in the 1970's, advertisers who were aggressive in spending during economic contractions increased net income at a higher rate than other companies with benefits increasing during and after the recessions (Kamber, 2002, p.107; American Business Press, 1979). Another well-known series of studies was conducted by the McGraw-Hill Laboratory of Advertising 
performance in the late 1970s and early 1980s. In this study there was a comparison of the business outcomes of firms that invested on advertising and those did not.

LAP reports provided additional graphic evidence about the companies that cut back advertising expenses during economic downturn suffered lower sales growth rates, especially during the 1981-82 recession, when companies reduced advertising spend, suffered growth rates of one-third that of the comparison group over the next five years (Kamber, 2002, p.107; LAP Report (undated)). A third source of data released by Strategic Planning Institute during the 1980s and 1990s. SPI, have focused on the relationship between media advertising spend and changes in return of investment covering recessions from 1974 to 1990 . These studies have used a very large historical database of business statistics and besides that they have been widely cited in the business press (Kamber, 2002, p.107; SPI, 1982; Hillier, 1999). Finally, the PIMS (Profit Impact of Market Study) studies show that organizations which continued to invest on marketing efforts and even increased their investments, did not make significantly less profit during recession; furthermore, companies that increased their marketing spending gained market share three times as quickly after the downturn (Hruzova, 2009; Roberts, 2003, Hiller, 1999).

Tellis and Tellis (2009), mentions about the reasons in favor of cutting back advertising that can be easily refuted as shown in Table 3.

Claim 1: "Consumers have less disposable income during recessions"

Rebuttal: Since 1940, the labor force may not have declined by more than $2 \% 1$. Similarly, consumers' disposable income has not declined by a large amount. However, advertising expenditures seem to decline more that the GDP or personal disposable income.

Claim 2: "Firms can cut back on advertising if competitors do too"

Rebuttal: Firms could also take advantage of the opportunity to seize market share from their competitors who are cutting back on advertising.

Claim 3: "Money can be reallocated to pay dividends."

Rebuttal: By cutting back on advertising, sales may decline during a recession. Alternatively, there may be a lost opportunity to build sales by advertising during a recession. These real or opportunity losses may be more in absolute value than the value to shareholders by paying out dividends. Money may be better invested in building sales and market share during a recession than in building investor faith in stocks.

Claim 4: "Resources could be better allocated to product development or R\&D, which would later turn greater profits during market expansions."

Rebuttal: In a declining market, sales response may be greater to advertising than to new products. Moreover, the cost of introducing new products may make that activity more profitable during expansion than during a recession.

Table 3: Claims and Rebuttals for Not Advertising in a Recession Source: Adapted from "Advertising During a Recession". Direct Marketing Sept 1991

Kamber (2002, p: 108) indicates that, there seems to be the domination of evidence to support the claim that maintained or increased advertising expenditures during recession are a logical business strategy. It would give rise to a higher return on investment and improved consumer buying disposition. Kamber states that, prior research did not indicate key factors such as business size, sector that can confound the relationship between advertising and business performance. He continues that larger companies for instance, have the resources to maintain advertising spending during downturns, while the smaller competitors were cutting back the expenses. Thus, the large companies would be more likely to sustain sales growth after recessions as a result of their established presence in the market and access to credit markets. Alternately, companies with high stock multiples may feel obliged to buy more advertising during a recession to maintain investor confidence. Yet, after recessions these businesses achieve high growth rates as a result of their support in the equity markets.

As stated in the findings of Kamber's study $(2002,117)$, Companies that sustained or increased advertising spending during the 1991 recession had a five-year sales growth, which was $\% 25$ higher as a whole, that companies that did not. Besides he found out that there is a positive correlation between advertising spend and sales. He indicated that change in advertising spending during a recession has a positive and statistically significant relationship to short-term sales. Moreover, the relationship between advertising expenditures and sales growth is strongest during recessions and times of economic turmoil, such as the 2001 dot-com boom.

As it is mentioned above existing studies showed positive relationship with economic growth and advertising, and companies with aggressive advertising during recessions increased sales and profitability over long term. Although authors agree on these stylized facts, would like to introduce some caution on how to evaluate these findings. The following segment will outline new approach on how to handle recession and advertising. 


\section{Further Considerations}

During recession times companies adjust their budgets to cut costs and manage their liquidity properly. Advertising is one the items considered. However, there are other expense categories firms may adjust such as research and development $(\mathrm{R} \& \mathrm{D})$, labor cost, raw material cost. In a way, along with advertising spending these other categories may substitute or complement each other. Some firms may choose to increase R\&D, while cutting back on advertising spending. Some others may increase adverting, while cutting back R\&D. They may cut both or increase both. Thus it is imperative to investigate substitution and complementary effects among alternate budget items. In doing so, firm's characteristics play an important role. Therefore, studies should control for various characteristics of firms. Following characteristics are suggested: industry, existing market share, financial position, and size. Accordingly contingencies should be established as such the impact of advertising during recession analyzed under these conditions. Similarly, advertising strategies followed during recession should be identified under these contingent elements. For example, companies with dominant market share may find it difficult to acquire new customers, since their marginal cost of acquisition is already high. On the other hand, firms with lower market share with low marginal cost of acquiring new customers may find advertising advantageous. In this case large firm, rather than spending on advertising to acquire new customers may be better off by implementing retention strategy for existing customers. Therefore, they may put more emphasis on communicating with their present customers to keep them happy. Instead advertising they are better off spending on $R \& D$ and develop new products or services. Once the recession is over, they introduce new line, and then start advertising.

Another factor to consider in analyzing the impact of advertising during recession has to do with advertising and price elasticities. Depending upon the product both elasticities will be different across products and may change along with business cycles (Sirinivasan, 2011, p.49-50). As the economy goes toward recession consumers may become more sensitive toward price, due to declining incomes. This may increase price elasticity. As for the advertising elasticity may increase while the economy goes into recession. This is less competitive clutter, thus customers notice individual firms or brands easily. Additionally, during recession times media prices declines. That enables companies to buy more advertising with same dollars (Heerde et.al 2013, Deleersnyder et.al. 2009). During economic downturns consumer become price conscious and ignore imagebase advertising, plus consumers would be less sympathetic toward advertising. If this were the case during recession advertising elasticity would be lower (Sethuraman, Tellis, and Briesch, 2011). As a result it not clear what happens to advertising elasticities during recession. Evidence provided by Heerde et.al suggest, in general, that during contraction advertising elasticities become larger compared with expansionary periods. Thus it is very important for managers to have good understanding about advertising and price elasticity's of their products or brands, including cross elasticity's in competitive environment in order to maximize sales.

\section{Conclusion}

In this paper authors reiterated that there is a positive correlation between advertising spending and changing business activity. However, businesses should not fall into a trap to reduce their advertising budgets during recessions, without carefully analyzing competitive landscape and their relative positions within their industry in terms of their size, market share, products etc. They have to consider all these elements in making decision to advertise more (less) or use alternate options available to them, like R\&D, price adjustments, or modifying their messaging to customers. Companies who properly evaluate alternatives can prosper during recession times by converting bad economic environment to an opportunity and set themselves to grow even further during expansionary times.

\section{References}

- American Business Press, 1979. "How Advertising in Recession Periods Affects Sales", American Business Press, New York.

- Belch and Belch, 2012. Advertising and Promotion: An Integrated Marketing Communications Perspective. McGraw-Hill. $9^{\text {th }}$ Edition.

- Deleersynder, Benedict, Steenkamp, Leeflang, 2009. “The Role of National Culture in Advertisings' Sensitivity to Business Cycle: An Investigation across Categories”. Journal of Marketing Research. Vol.46. October.pp.623-636.

- Direct Marketing, 1991. “Advertising During a Recession”. September: http://www.allbusiness.com

- Global Media Report, 2013. Mc Kinsey and Company. Wilkofsky Gruen Associates

- $\quad$ Ferrell, Hartline, 2002. Marketing Strategy. Thomson South-Western, United States of America. 4th Edition.

- Heerde, Gijsanberg, Dekimpe, Steenkamp, 2013. "Price and Advertising Effectiveness over the Business Cycle". Journal of Marketing Research, Vol.1, pp.177-193. 
- Hillier, 1999. "Successful Competitive Strategies for Recession and Recovery, Evidence from PIMS, in Barwaise, P. (Ed.) “Advertising in a Recession”, London Business School, London.

- Hruzova, 2009. Marketing Strategies during Financial Crisis. Masters Dissertation. Halmstad University.

- Kamber, 2002. “The Brand Manager's Dilemma: Understanding how advertising expenditures affect sales growth during a recession.” Brand Management, Vol.10. No.2 pp.106-120.

- Laboratory of Advertising Performance / McGraw-Hill Research (undated), LAP Report \#5262, McGrawHill Publications, New York.

- $\quad$ Roberts, 2003. "What strategic investments should you do during a recession to gain competitive advantage in the recovery?" Strategy \& Leadership, Vol. 31, No. 4, pp. 31-39.

- Sethuraman, Tellis, Briesch, 2011. "How Well Does Advertising Work? Generalization of Meta Analyses of Brand Advertising Elasticities". Journal of Marketing Research, 48 (June), pp.457-471.

- Shrager, 1991. "Corporate growth strategies in a recession.” The Corporate Growth

- $\quad$ Report, Vol. 9, No. 2, pp. 4-5.

- Srinivasan, Lilien, Sridhar, 2011. "Should Firms Spend More on Research and Development and Advertising During Recessions?” Journal of Marketing. Vol.75, pp.49-65.

- Srinivasan, Rangaswamy, Lilien, 2005. "Turning adversity into advantage: Does proactive marketing during recession pay off?” International Journal of Research in Marketing, No. 22, pp. 109-125.

- Strategic Planning Institute, 1982 "Media Advertising When Your Market is in a Recession"

- Tellis and Tellis, 2009. "A Critical Review and Synthesis of Research on Advertising in a Recession": http://gtellis.net/Publications/AdReview.pdf ,03.04.2014

- "Turkish Business Cycle Contractions": http://www.turkstat.gov.tr/, 01.01.2014

- US Business Cycle Contractions: Source: http://www.nber.org/cycles/cyclesmain.html, 01.04.2014

\section{Appendix: Global Advertising by World Regions}

Advertising is highly sensitive to the economy, and the recession in 2009 and weak economic growth over the past two years have hurt the global advertising market. Improving economic conditions will provide a lift.

\begin{tabular}{|c|c|c|c|c|c|c|}
\hline Region & 2007 & 2008 & 2009 & 2010 & 2011 & $2012 p$ \\
\hline North America & 171.410 & 163.305 & 139.854 & 149.302 & 154.386 & 163.804 \\
\hline \multicolumn{7}{|l|}{ EMEA } \\
\hline Western Europe & 101.888 & 101.008 & 90.463 & 96.334 & 98.269 & 97.504 \\
\hline $\begin{array}{l}\text { Central and Eastern } \\
\text { Europe }\end{array}$ & 13.160 & 14.204 & 11.712 & 13.088 & 14.686 & 15.56 \\
\hline Midle East / Africa & 7.215 & 8.429 & 7.348 & 8.064 & 7.865 & 7.958 \\
\hline EMEA Total & 122.263 & 123.641 & 109.523 & 117.486 & 120.820 & 121.022 \\
\hline Asia Pacific & 108.968 & 112.41 & 107.169 & 118.099 & 125.855 & 137.021 \\
\hline Latin america & 17.457 & 19.498 & 19.929 & 23.965 & 26.212 & 28.854 \\
\hline Total & 420.098 & 418.854 & 376.475 & 408.852 & 427.273 & 450.701 \\
\hline
\end{tabular}

Table 4: Global advertising by region (US \$ millions) Source: Adapted from “Global Media Report, 2013”, McKinsey\&Company, Wilkofsky Gruen Associates 


\begin{tabular}{|l|c|c|c|c|c|c|}
\hline Region & $\mathbf{2 0 0 8}$ & $\mathbf{2 0 0 9}$ & $\mathbf{2 0 1 0}$ & $\mathbf{2 0 1 1}$ & $\mathbf{2 0 1 2 p}$ & $\begin{array}{c}\mathbf{2 0 0 7 - 2 0 1 2} \\
\text { CAGR }\end{array}$ \\
\hline North America & -4.7 & -14.4 & 6.8 & 3.4 & 6.1 & -0.9 \\
\hline EMEA & & & & & & \\
\hline Western Europe & -0.9 & -10.4 & 6.5 & 2.0 & -0.8 & -0.9 \\
\hline $\begin{array}{l}\text { Central and Eastern } \\
\text { Europe }\end{array}$ & 7.9 & -17.5 & 11.7 & 12.2 & 6.0 & 3.4 \\
\hline Midle East / Africa & 16.8 & -12.8 & 9.7 & -2.5 & 1.2 & 2.0 \\
\hline EMEA Total & 1.1 & -11.4 & 7.3 & 2.8 & 0.2 & -0.2 \\
\hline Asia Pacific & 3.2 & -4.7 & 10.2 & 6.6 & 8.9 & 4.7 \\
\hline Latin america & 11.7 & 2.2 & 20.3 & 9.4 & 10.1 & 10.6 \\
\hline Total & $-\mathbf{0 . 3}$ & $\mathbf{- 1 0 . 1}$ & $\mathbf{8 . 6}$ & $\mathbf{4 . 5}$ & $\mathbf{5 . 5 0}$ & $\mathbf{1 . 4}$ \\
\hline
\end{tabular}

Table 5: Global advertising growth by region (US \$ millions) Source: Adapted from "Global Media Report, 2013”, McKinsey\&Company, Wilkofsky Gruen Associates 